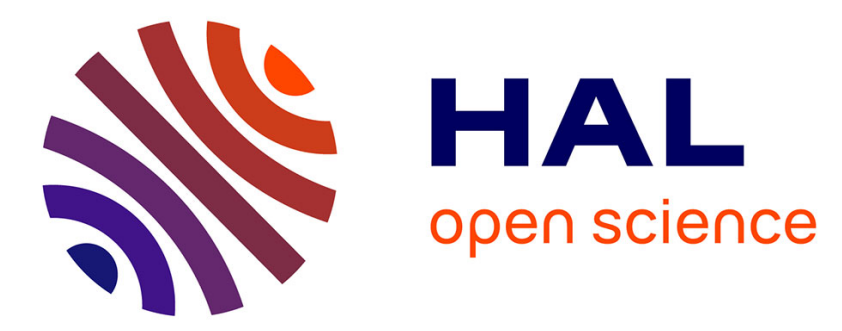

\title{
ICT the Nordic Way and European Retail Banking
} J. Carles Maixé-Altés

\section{To cite this version:}

J. Carles Maixé-Altés. ICT the Nordic Way and European Retail Banking. 4th History of Nordic Computing (HiNC4), Aug 2014, Copenhagen, Denmark. pp.249-262, 10.1007/978-3-319-17145-6_27 . hal-01301416

\section{HAL Id: hal-01301416 https://inria.hal.science/hal-01301416}

Submitted on 12 Apr 2016

HAL is a multi-disciplinary open access archive for the deposit and dissemination of scientific research documents, whether they are published or not. The documents may come from teaching and research institutions in France or abroad, or from public or private research centers
L'archive ouverte pluridisciplinaire HAL, est destinée au dépôt et à la diffusion de documents scientifiques de niveau recherche, publiés ou non, émanant des établissements d'enseignement et de recherche français ou étrangers, des laboratoires publics ou privés. 


\title{
ICT the Nordic Way and European Retail Banking
}

\author{
J. Carles Maixé-Altés \\ Department of Applied Economics 1, University of A Coruña, Spain \\ maixe@udc.es
}

\begin{abstract}
This paper discusses the world industry of savings banks, a genuine world collaborative consortium, through which, from the 1950s, the International Savings Banks Institute (nowadays, the World Savings Banks Institute and European Savings Banks Group) was highly active in introducing ICT to retail banking. In this environment, Nordic savings banks, Sweden, Norway, Finland and Denmark, their Central Savings Banks and their industry associations occupied a separate place in European movements around developments of computerization and automation in retail financial services. The synergies in Nordic countries were superior to the rest of Europe and collaboration was intense. This paper highlights the leadership and the influence that the ICT development models of Nordic savings banks had on their European retail banking associates.
\end{abstract}

Keywords: computers, savings banks collaboration, retail banking, Europe, Nordic countries, technological change

\section{Introduction}

This paper presents an overview of some of the processes which led Scandinavian savings banks in the field of ICT, especially between the 1960 s and the $1980 \mathrm{~s}^{1}$. Secondly, it emphasizes the importance of the collaboration in the Nordic Savings Banks industry, and finally, it shows the leadership and influence that the ICT development models of Nordic savings banks had on their European retail banking associates. New information from the International Savings Banks Institute (ISBI) provides us with a more precise interpretation of some aspects of the processes of ICT development in Nordic countries with reference to previous work (see specifically papers in $[7,8]$, and also [25,32].

Analytically, this paper proposes a double point of view. On one hand, Nordic countries are considered as early adopters of computer technologies and, simultaneously, as being integral to the processes of dissemination and appropriation of foreign models (an analytical framework developed by $[1,5,31])^{2}$. On the other hand, this work is set in the framework established by James Cortada and JoAnne Yates on the

\footnotetext{
${ }^{1}$ The concept of ICT will be used in its looser sense, basically referring to computer technologies and their applications.

${ }^{2}$ See also [32], [33].
} 
role that industries play in the introduction and development of ICT $[4,40]$, which is very relevant in an industry with a strong collaborative tradition such as those of savings banks $[2,26]$.

The remainder of the paper proceeds as follows. In the second section, the first stages of collaborative strategies in Scandinavian savings banks will be considered. In the third, the Nordic electronic data processing cooperation will be evaluated in general. The fourth section studies the most emblematic case of this collaboration: Nordisk Spardata. Next, some aspects of the ICT Nordic advantage will be dealt with, taking the Swedish case as a reference point. The sixth section considers the role that Nordic initiatives had for European retail banking. Finally, some concluding remarks.

\section{Early Collaborative Strategies}

Savings banks of Nordic countries very soon developed collaborating policies at national level. In this they followed the tradition of other European, North American and other worldwide institutions. Many of these (non-profit financial institutions or mutual organizations) always aimed to collaborate with their "sister institutions" to facilitate their economic and social objectives [34]. Table 1 shows the early formation of national associations of the industry and the later creation of the Central Savings Banks as wholesale of retail finance. The latter arose as a consequence of the increasingly intense role that savings banks had in domestic economies, channelling their savings and financing household economies. These circumstances reinforced the collaborative spirit of savings institutions in a natural manner.

Table 1. Savings banks associations and central savings banks in Nordic countries $[9,16,23]$

\begin{tabular}{|c|c|c|c|c|}
\hline Country & Entity & Headquarters & 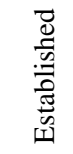 & Status \\
\hline \multirow[t]{2}{*}{ Denmark } & Fællesbanken & Copenhagen & 1919 & Central savings banks \\
\hline & $\begin{array}{l}\text { Danmarks Sparekassefore- } \\
\text { ningen }\end{array}$ & Copenhagen & 1947 & Savings banks association \\
\hline \multirow[t]{2}{*}{ Finland } & Suomen Säästopankkiliitto & Helsinki & 1823 & Savings banks association \\
\hline & Skopbank & Helsinki & 1908 & Central savings banks \\
\hline \multirow[t]{2}{*}{ Norway } & Sparebankforeningen i Norge & Oslo & 1914 & Savings banks association \\
\hline & Union Bank (ABC Bank) & Oslo & 1919 & Central savings banks \\
\hline \multirow[t]{2}{*}{ Sweden } & $\begin{array}{l}\text { Svenska } \\
\text { Sparbanksföreningen }\end{array}$ & Stockholm & 1900 & Savings banks association \\
\hline & Swedbank & Stockholm & 1942 & Central savings banks \\
\hline \multirow{4}{*}{$\begin{array}{l}\text { Nordic } \\
\text { countries }\end{array}$} & Nordic Central Savings Bank & Copenhagen & 1931 & Regional central savings \\
\hline & $\begin{array}{l}\text { Associations Delegation } \\
\text { (NCSD) }\end{array}$ & Helsinki & & banks association \\
\hline & & Oslo & & \\
\hline & & Stockholm & & \\
\hline
\end{tabular}


In the 1970s, legislation allowed greater diversification in the savings banks operations (i.e. savings banks regulation from 1961, Sweden). This new framework meant that, in general, savings banks could gradually develop a new profile as business-oriented banks, maintaining their traditional relationships with households. This trend incentivized even more the adoption of new technologies and collaboration.

\section{The Nordic Electronic Data Processing Cooperation}

The firmest evidence of institutional cooperation between the group of Nordic savings banks appeared in 1931 with the creation of an association of the central savings banks of Nordic countries which very soon had seats in each of the four Nordic capitals (see Table 1). This collaboration took place in an institutional framework which was favorable at national level, whereby initiatives were given such as the creation in 1951 of the Nordic Council, an inter parliamentary forum which led to various areas of cooperation between the Scandinavian countries) [23].

However, it was in the 1960s that the electronic data processing (EDP) cooperation took a big step forward. Setting up national data centers in Sweden, Denmark, Norway and Finland was the key (see Table 2). In this regard, developments in computer technologies (with the second generation of computers and above all the third generation) notably affected retail banking. New computers improved the possibilities of automatizing back office and front office processes, which would revolutionize banking management. The role of third generation computers was really crucial, as they opened up a field of development in the on-line, real-time (OLRT) field, fundamental for institutions such as many European savings banks, which covered extensive branch-office networks ${ }^{3}$.

In Nordic countries, a similar problem occurred as in the rest of Europe as to what was the most suitable computerization policy: one's own resources or shared computer resources via data center companies or shared data centers. In those early times of computerization, Nordic savings banks opted for data centers shared between various savings banks. In the rest of Europe, very varied trends took place, depending on regional cases (Spanish savings banks opted for their own resources, German ones for mixed systems, and British ones later opted for shared resources to quote just a few significant examples) [17,20].

The need to develop online technologies to connect the data centers with banking offices emerged from the new data centers. The technological change required wider collaboration, which implied greater institutional development in collaborative structures. This objective fully covered the eventual late 1960s creation of Nordisk Spardata (Nordic Savings Data) (hereafter NS), a common organization between the four Nordic countries [18]. Throughout the 1970s and 1980s, the range of technological development projects expanded in the Northern countries' enhancement of online processes through the OLRT systems and rationalization of payment systems amongst

\footnotetext{
${ }^{3}$ Specifications on the subject of OLRT in [28].
} 
others. Clearly this paper does not aim to present an exhaustive discussion of the subject. Therefore only some significant cases will be dealt with.

The intensity of the Nordic collaboration was incentivized by the energetic technological change which led to the introduction of ICT in retail banking. In economic terms, it was the need for better productivity of banking operations as well as the growing competition of the commercial banking sector (within a framework of growing transaction costs, see [37]), which pushed the savings banks in this sense. At the end of the 1960s, Swedish savings banks, for example, experienced strong competition from the networks of branches of commercial banks [19], which was a further reason to justify the continuous movement of concentration in the sector [6,37].

Table 2. Savings Banks Data Center Companies at 1969 in Nordic Countries [17]

\begin{tabular}{|c|c|c|c|c|c|c|c|c|}
\hline & \multirow[b]{2}{*}{$\begin{array}{l}\text { Company (year of } \\
\text { stablisment) }\end{array}$} & \multirow[b]{2}{*}{ Legal entity } & \multirow[b]{2}{*}{ Data Centres } & \multicolumn{4}{|c|}{$\begin{array}{c}\text { Participating Savings } \\
\text { Banks } \\
\end{array}$} & \multirow[t]{2}{*}{ Financing } \\
\hline & & & & $\dot{\mathrm{z}}$ & $d^{0}$ & 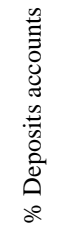 & 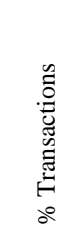 & \\
\hline 㫕 & $\begin{array}{l}\text { Sparekassernes } \\
\text { Data Centraler, } \\
\text { SDC (1963) }\end{array}$ & $\begin{array}{l}\text { Cooperative } \\
\text { Society }\end{array}$ & $\begin{array}{l}\text { Copenhagen, } \\
\text { Aarhus, } \\
\text { Odense }\end{array}$ & 112 & 29.2 & 45.4 & 52.5 & $\begin{array}{l}\text { Loans of the } \\
\text { participating } \\
\text { banks }\end{array}$ \\
\hline 营 & $\begin{array}{l}\text { Department of } \\
\text { Säästöpankkien } \\
\text { Keskus-Osake- } \\
\text { Pankki (1966) }\end{array}$ & $\begin{array}{l}\text { Savings Banks } \\
\text { Central Bank }\end{array}$ & Helsinki & 38 & 11.0 & 17.1 & 23.6 & $\begin{array}{l}\text { Savings Banks } \\
\text { Central Bank }\end{array}$ \\
\hline 光 & $\begin{array}{l}\text { Fellesdata A/S } \\
\text { (1965) }\end{array}$ & Joint stock Co. & Oslo & 33 & 6.4 & - & 25.0 & $\begin{array}{l}200 \text { shareholders } \\
\text { and Central } \\
\text { Bank }\end{array}$ \\
\hline$\frac{5}{\tilde{d}}$ & $\begin{array}{l}\text { Sparbankernas } \\
\text { Datacentrales AB, } \\
\text { SPADAB (1961) }\end{array}$ & Joint stock Co. & $\begin{array}{l}\text { Stockholm, } \\
\text { Göteborg, } \\
\text { Malmö and } \\
\text { Linköping }\end{array}$ & 140 & 43.0 & 87.0 & - & $\begin{array}{l}\text { Small share } \\
\text { capital } \\
\text { and loans of } \\
\text { participating } \\
\text { banks }\end{array}$ \\
\hline
\end{tabular}

\section{Nordisk Spardata}

The first steps of a technological collaboration, firmly set in ICT between the savings banks of Nordic countries, occurred half way through 1968. NS originated as a common organization between the four Nordic countries, whose aims were to develop research work, which would allow the introduction of new systems and programs in the field of computer technologies. The plan (around which the creation of NS was managed and consolidated) was the coordination of a common project to 
design and make a new teller terminal. The unionized agreement was signed between the Swedish and Danish savings banks in March 1969, and Finland and Norway joined respectively at the end of 1969 and at the beginning of 1970 [24].

In November 1971, during the 5th Conference on Automation in Vienna, Peder Erik Larsen (Managing Director of Falster-Östlolland Savings Bank, Denmark, and Chairman of NS), highlighted some of the aims of the new organization:

- To develop common instructions (standardization-documentation) for EDP (Nordic EDP Manual)

- To advance common programs for the processing accounts

- To make statistical models and operation research models

- To develop Nordic Terminal Project (NTP)

- To improve staff training (techniques for the use of equipment)

The respective EDP savings banks organizations were involved in the birth of this organization. They were very interested in developments related to EDP on a common basis, a journey which had already started with the NTP.

\subsection{Nordic Terminal Project, DATASAAB (Saab-Facit)}

The advantages offered by the new computer networks and online connections (teleprocessing) revolutionized retail banking. With the experience of the USA as a starting point, the Swedish and Danish banks tried to adapt it to their national cases. US savings banks were characterized by large units with few and large branches, not too far from the Headquarters, unlike the Nordic structure with its many branches scattered over an extensive geographical area. The need to develop online systems and the high costs of their development depending on the equipment available (especially teller terminals) was considered an obstacle to isolated national solutions both in Sweden and in Denmark [24].

Increasing Collaboration on Data and Knowledge. From here, common discussions began with the objective of defining the requirements of common online terminal equipment, and also finding possible suppliers of such terminal equipment. Simultaneously, Erik Forslund (Stockholm), coordinator of the technical committee of the four organizations of Nordic savings banks, travelled to Japan. The Scandinavian representative was interested in learning about the agreement made between Toshiba, Hitachi and Nippon Electrics to build a teller terminal for the Japanese Post Office Savings Banks (manufacturing 24,000 terminals at a price $10 \%$ lower than the IBM terminal) [18].

15 offers were received from international suppliers (including USA and Japan). In the summer of 1969, a joint offer from the Swedish companies Saab-Scania AB 
and Facit AB was accepted [18], [24] ${ }^{4}$. The Project's promoters were aware that the NTP had to fulfill very flexible specifications, as demand was very disparate in each of the Scandinavian countries. For this reason, the final project adopted a modular structure, which could adapt to each of the surroundings in which the equipment would be placed.

Finally a basic contract was signed between Saab and the organizations of NS, whereby purchasing agreements were made of a certain number of units. At the end of 1971, the pilot installation was available and the mass production of terminals began half way through $1972[18,23]$. The new banking terminal aimed at a potential Nordic market including 1,600 savings banks, 5,200 banking offices, deposits for a value of \$ 10,625 million and approximately 21 million accounts [23]. The Project developed well between 1972 and 1975 whereby approximately 15,000 terminals were installed in Nordic countries and in Spain, USA, France, Great Britain, Austria, Belgium and Holland [12], [29]. On the 9 of May 1972, the first terminal in the Vaasa Savings Bank (Finland) was operational. The words of the President of NS in the Vaasa presentation were significant:

"To my knowledge, the terminal Project is the largest joint Project ever undertaken in Scandinavia [...] Bank enterprises in the Continent have long attempted to find common solutions to technical problems but have failed to make much progress to date" [14].

The Project's implications in terms of human resources training were huge. A central and local training plan was established using modern training systems and materials for self-learning. It was the first time in Scandinavian countries that a technical educational program directed at a wide range of computers was applied. Between 12,000 and 15,000 people participated in the training courses on terminals in this first stage [23].

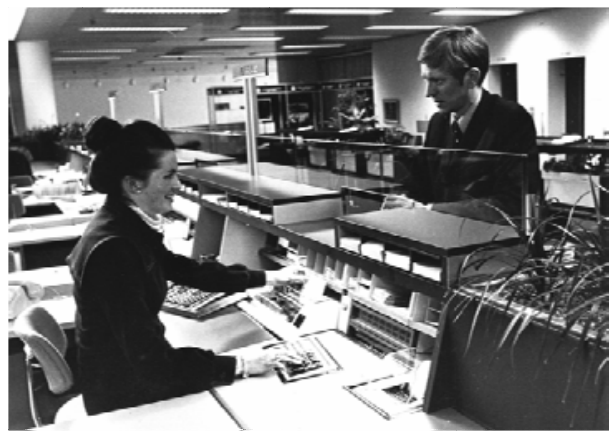

Fig. 1. The Nordic financial terminal, DATASAAB teller terminal (1972), was one of the first common projects of Nordisk Spardata (Nordic Savings Data), the Nordic savings banks' joint company for new technological projects from 1969. Courtesy of J. Ruiz Kaiser, Barcelona.

\footnotetext{
${ }^{4}$ Saab-Scania became the prime contractor with primary responsibility and Facit was included as a sub-contractor to Saab-Scania with the task of supplying most of the terminal modules. See also about Facit [33] and about Datasaab [21], [29], [38].
} 
Technical Specifications. From the fall of 1970, a working group made up of computer center representatives from each country (NS) was set up in Linköping (Sweden). The aim was to work with the staff of Saab-Scania AB and Facit AB in that locality. Likewise, the developments of the Nordic terminal required intense collaboration with IBM, the supplier of the hubs for Danish and Swedish online systems. In fact during the trial phase, various compatibility tests were carried out at La Gaude, France (November 1972), in an attempt to evaluate the Datasaab D5 minicomputers, IBM concentrators and the data processing hardware [15].

The banking terminal could operate offline and online. In the former case, it worked independently from the computer center, and transactions were gathered onto a cassette tape and sent to the data processing center. In the case of online operations, transmission was done via point-to-point telephone lines with the computer center 5 . Maybe Datasaab's most competitive feature was that it sowed the seeds for future terminal developments with a more advanced concept than that of IBM. These terminals had control elements which until now had been located in the host. The evolution towards smart terminals was started [27].

Two types of terminals directed at banking branches were manufactured: cash registers and query terminals. Moreover, a combination of both existed.

Teller equipment was made up of the following basic units $[14,15,39]$ : a key unit, (to unblock the terminal and choose the way of working - off line or online), a numerical keyboard (selecting transaction type and for entering figures during transactions), an indicator panel (a work operation control in a teller terminal by means of a plain language display of the different data entry phases), a printing unit to tally ledgers, a printing unit for documents and pass-books, a numerical indicator (visual control of numerical information entered), and a D5 minicomputer (the heart of the system), this hardware controls and monitors the operation of modules and is responsible for communication with the computer center in online operations. Non basic units were a printing unit for an addition strip, a tape printer, an alphanumerical keyboard, a document printer, cassette tape storage and a CRT terminal [30].

Creating Value for Customers and Savings Banks. Palle Lundberg, NTP's Project leader, was without doubt highly knowledgeable about the Project's technical basis and also a firm defender of its implications in the field of improving the quality of the services offered by the industry. In May 1972, he presented his ideas on the following five points:

- From the point of view of savings banks, the introduction of the new terminal implied a significant saving of work. It eliminated key-punching and preparation procedures regardless of whether the terminal was connected online or offline. The new systems provided a central information file from which the savings banks could acquire a picture of the customer's relations with the bank.

- From the employees' point of view. The transition from the online to the OLRT system facilitated savings banks activities such as updating entries. The individual teller found the new working station designed in accordance with the highest

\footnotetext{
${ }^{5}$ More details on teleprocessing networks [26]
} 
standards. The new terminal provided the teller with a frontal layout with a position facing the customer. This layout was achieved as a result of close collaboration between human engineers and other scientists (see Figure 1).

- The significance of the terminal to the computer centers. The terminals gave no immediate savings for the computer centers (investments in larger and more expensive equipment in order to accommodate the terminal system). However with the aid of larger computers, the data processing centers would be able to process transactions more quickly. This is a key factor in the context of the growing numbers of transactions.

- The significance to the individual customer. This was a vital point. Automatic updating of pass-books and faster response to queries would be examples of customer benefits in a real-time system. The processing of loan applications from a central information file, information about payroll transfers or other transfers were involved. At the end, automatic updating would mean that a customer's account would be automatically adjusted via the central system, and the answer would be then displayed in a few seconds.

- Future system of payment implications. The installation of the new equipment created the necessary infrastructure to develop and apply the new products which were installed in the payment systems (debit and credit cards, automated teller machines (ATM) and electronic points of sale (EPOS) amongst others).

Premonitory words in the early 1970s:

"The press and TV often speak of the "cashless society", credit cards etc. They both demand the development of an extensive system of terminals. Savings banks have chosen to take the lead here. But ultimately all banking houses, department stores, shopping centres and, perhaps, every home may follow suit so that all payment transactions can be made via an integrated data network without the use of cash or cheques" [14].

The great advance which the "Nordic terminal" implied was its great flexibility. Terminal modules could be replaced by more advanced models or completely new modules, such as a credit card reader. Cash dispensers could also be connected to the central computer via a terminal minicomputer.

\subsection{Common management systems}

The Scandinavian EDP handbook was the first of the joint projects. Effective collaboration means common standards for documentation are needed. Therefore all four countries took part in the task of designing a joint EDP handbook. NS also worked on a joint accounting system project, a high-priority project. The introduction of a common account chart would mean that the four countries would have a common starting point in respect to ordinary accounting and in the development of a management information system (MIS) [23].

Also here, with the Swedes' and Danes' collaboration with NS, a development Project of statistical and operational research models, (which could be useful to the savings banks in various decision making situations) was set up. Scientists from Lund University in Sweden carried out the development work. This collaboration was very 
effective, as over a short while various results based on multi-stage linear programming models were obtained [3].

One of these was a cash-fund model, whereby the savings banks could determine the amount of on-hand cash necessary in the branch offices. Another was a model for teller line computer simulation (teller unit queuing model), which has been developed to analyze the maximum number of teller units, which need to be open at different times of the day. In addition to these two models, together representing a teller unit dimensioning system, a loan model was also developed for the evaluation of risk and prospective customer behavior. Finally, an asset management model which was to provide savings banks with the opportunity of evaluating different investment alternatives $[23,24]$.

\section{The Nordic Advantage}

As regards the industry of Nordic savings banks, ICT development was the product of the fortunate conjunction of individual initiatives, unionized initiatives from the national associations of industry and finally the convergence of all these via transnational agreements, which integrated industry associations of the four Nordic countries. In this sense, each of these collaboration and integration routes had sufficient autonomy to prevent any collapse.

In the interests of size and opportunity, this paper uses the Swedish case to specify some significant aspects of the Nordic advantage. As we have mentioned, Swedish savings banks developed their computer centers (SPADAB as a data processing company) which expanded throughout the entire country (see Table 2). Likewise, numerous companies which were specialized in the service of Swedish savings banks developed. From 1966, SPADAB itself began a series of corporate movements in order to integrate new activities into its associates' services. In 1969, through acquisition, it managed to create a new company, Samdata, which provided it with greater diversification of products. Until the middle of 1970, there was no competition for Samdata which could offer an efficient wage and salary system for a broad market, as well as a book-keeping system and an analysis of variances, accounts receivable, invoicing and stock-keeping [13,35]. The expansion process continued when in 1977 another corporate movement was completed which permitted the access to mini computers (a way of avoiding the competitive pressure which took place between the central bureau services and the installation of mini computers by clients) [11].

One must also highlight the role of Sparbankernas Arkitektkontor Och Centralupphandling AB (SAC) [Architect's Office \& Central Purchasing Department of the Swedish Savings Banks], which covered a wide variety of initiatives in the 1970s and 1980s. Business of the type covered by SAC has gradually developed within the framework of Sparfrämjandet (the Swedish savings Banks bureau for advertising and economic information $)^{6}$, founded in 1942 and the oldest company in the large group of companies associated with the Swedish Savings Bank Association. SAC acquired a more efficient organizational form in 1970. At the start of the 1970s, SAC

\footnotetext{
${ }^{6}$ This was formally involved in the development of Swedish ATMs [37].
} 
had an annual turnover of approximately US \$ 8.2 million and over 100 employees [36].

Similarly, the development of an ATM system in the Nordic environment was the result of a series of entrepreneurial initiatives although it experienced some difficulties $^{7}$. Jan Rydh, Director of SPADAB, informed people in the 17th Meeting of Business Organization and Administration Committee of the ISBI (Bonn, 1975) that the development of the new cash dispensers would continue in Swedish hands, as the rest of the Nordic countries considered it unlikely to be able to install these equipment over the next two years. The Swedish firm was considering placing an order of 400 units at the end of the year. Swedish savings banks then had 100 Asea-Metior cash dispensers, which performed some 800,000 annual transactions with a base of 50,000 cards [12]. Indeed this reticence encouraged SPADAB to offer ISBI a celebration of a seminar in Sweden, held in the fall, to discuss the subject in the framework of NS. It provided ample information on the services of cash dispensers, marketing policies to incentivize their use and the standardization of cards. The results of this and other initiatives favored a recuperation of Nordic collaboration in this field which converged with the projects of the Nordic terminal and the development of the OLRT (they eventually opted for the manufacturer Docutel, a US based Company, whose ATMs from 1983 gave way to the new generation of Ericsson CAT automatic tellers) $[12,10]$.

Finally, as an example of the Swedish collaborative phenomena which went beyond its actual industry, the development in the 1980s of the Savings Banks Consortium should be mentioned. This was the result of an agreement at the beginning of 1983 between Swedish savings banks, their central savings bank and seventeen large banks to activate central capital markets, enterprises and organizations covering all of Sweden. Another joint initiative, among others, was the Backup-centralen $A B$ with SPADAB's participation [10].

\section{Implications for European Retail Banking}

The previous sections have shown some of the issues, which were most interesting for European savings banks in the field of ICT. They give a necessarily brief picture of the situation. However, this allows an approach to the synergies which were established between European retail banking and the role that Nordic initiatives had in that context.

Since it took its first steps, the subject of the Nordic terminal had a major repercussion amongst the rest of European savings banks. In the 4th Conference on Automation, October 1969 (Sitges, Barcelona), reports and debates on the NTP's first initiatives were intense. The Institut für Automation der Deutchen Sparkassen und Girozentralen (IFA) in Germany was also very interested in the Nordic project, precisely because German specifications were very similar. In turn, Austrian savings banks especially valued the adaptability to different computer programs of the terminal [18]. Indeed an ad hoc collaboration with the IFA was adopted. Another conse-

\footnotetext{
${ }^{7}$ See [37] for further information on Swedish ATMs.
} 
quence of this interest around the Nordic initiative was a "Report about the terminal Project” from the ISBI Terminal Project Working Group on 31 October 1972. This was a very documented and thorough report, whereby the combination of problems was considered, and it also dealt with technical problems which involved the group of worldwide manufacturers, including Nordic ones [16].

Evidently the problem around terminals was clearly connected to the development of the entered OLRT processes, a task which concerned many European savings groups. In this field, there were great differences amongst European countries due to the different territorial characteristics of savings banks, their size and the extension of the networks of the subsidiaries (local, provincial, regional and national). From the end of the 1960s, Nordic and German savings banks, and some from the south of Europe (especially Spanish ones) presented advanced processes in these fields. Others like the British TSB and the French caisses d'épargne were slower [2], [17], [39]. In this sense, the most advanced countries in the field exerted considerable influence, leading projects and initiatives as shown by the components of the ISBI's ad hoc working groups and committees ${ }^{8}$.

The other large subject which quickly developed through the 1970s was that of the EPOS systems and issues related to payment systems. In fact, in the ISBI under the Nordic initiative, half way through the decade, a restructuring of the various committees and working groups took place. This reorganization led to new concerns for savings banks, channeling the issue of terminals and automated tellers towards the problem of the future payment system [12].

Eventually the dynamics established by Nordic savings banks on the creation of subsidiary companies had a great influence on their European colleagues. These subsidiary companies offered services to savings banks and their clients, especially in the field of ICT. Some of the errors initially committed in the Nordic area were dealt with in the various ISBI committees. In the years when hardware was not compatible and computers programs were designed ad hoc, the influence of erroneous businesses was plentiful. Therefore the proportionate learning for these case studies produced interesting synergies [10], [35].

Significantly, by the end of the nineteen seventies and start of the nineteen eighties, the Nordic experience and that of many European savings banks was converging towards common lines of business policy: the design of standard IT packages (ad hoc products had high personnel costs), specialization (construction, engineering, the car industry and finance) and the use of the savings banks' own methods to sell services [11].

${ }^{8}$ Between the sixties and eighties, Scandinavians, Germans and Spanish were members of this working group: Per Olov Rimvall, Erik Forslund and Jan Rydh, Stockholm; Palle Lundberg, N. A. Nielsen and Mogens Christiansen, Copenhagen; Peder Erik Larsen, Nyköbing; Roland Zeitler and R. Novak, Frankfurt; M. Müller, Bonn; Jesus Ruiz Kaiser, Barcelona; Antonio Galán, Madrid amongst others. 


\section{Concluding Remarks}

Two factors can be cited as being integral for Nordic identity in the field of introducing and disseminating ICT. On one hand, the intense collaborative structure of its saving banks, and on the other, what we could call outsourcing avant la lettre, that is to say a business framework created for savings banks and their associations, which favored this commitment within the framework of growing competition ${ }^{9}$.

The Nordic case highlights the important role of industries in providing and developing computer technologies. This line of reasoning which was pointed out by JoAnne Yates and James Cortada is reinforced by the intense collaboration between the four Scandinavian countries.

The evidence presented suggests that the Nordic model participated in the technological change, both as an early adopter of computer technologies and as being integral to their diffusion processes. In the first case by resorting to its own manufacturers (i.e. Datasaab developments) and in the second by adopting foreign technologies and even using these to develop more suitable models (i.e. the evolution of cash dispensers and the role of US based companies and subsidiaries), see [25], [32]. Finally, the factors studied, collaboration and technological change, have profound economic bases: growing competition in the banking industry and rising transaction costs, on the whole, a necessary improvement of productivity.

\section{References}

1. Alberts, G.: Appropriating America: Americanization in the History of European Computing. Annals of the History of Computing, IEEE, 32(2), 4-7 (2010)

2. Batiz-Lazo, B., \& Maixé-Altés, J. C.: Organizational Change and the Computerization of British and Spanish Savings Banks, circa 1950-1985. In: Batiz-Lazo, B., Maixé Altés, J.C. and Thomes, P. (eds.), vol. 20, pp. 137-154. Routledge, New York, London (2011)

3. Bjerke, B.: Dinamic Balance-Shit Planning. 5th Conference on Automation, ISBI, Vienna (1971)

4. Cortada, J. W.: The Digital Hand. How Computers Changed the Work of American Financial, Telecommunications, Media and Entertainment Industries. Oxford, New York, Oxford University Press (2006)

5. Eglash, R., Croissant, J. L., di Chiro, G. et al. (eds.): Appropriating technology: vernacular science and social power. University of Minnesota Press, Minneapolis (2004)

6. Forsell, A.: Moderna tider i sparbanken: Om organisatorisk omvandling i ett institutionellt perspektiv. Nerenius \& Santérus förlag, Stockholm (2002)

7. Impagliazzo, J., Lundin, P., Wangler, B. (eds.): History of Nordic computing 3. IFIP AICT, vol. 350. Springer, New York (2011)

\footnotetext{
${ }^{9}$ On outsourcing, see [22].
} 
8. Impagliazzo, J., Jäervi, T., Paju, P. (eds.): History of Nordic computing 2. IFIP AICT, vol. 303. Springer, Berlin (2009)

9. ISBI: International Savings Bank Directory. International Savings Bank Institute, Amsterdam (1987)

10. ISBI: Members Report. Business Organization and Automation Committee, International Savings Banks Institute, Amsterdam (1983-04-20, BA-293) (1983)

11. ISBI: Minutes of the 17th Meeting of the Business Organization and Automation Committee. BOAC, International Savings Bank Institute, Stockholm (1978)

12. ISBI: Minutes of the 11th Meeting of the Business Organization and Automation Committee. International Savings Bank Institute, Bonn (BA-105, 1975-06-27) (1975)

13. ISBI: Central Information System in Savings Banks. Results of an Investigation. International Savings Banks Institute, Geneva (1972.)

14. ISBI: Press release, Copenhagen, Helsinki, Oslo, Stockholm, 9 May 1972, (1972a)

15. ISBI: Datasaab's Terminal System, Technical Specifications. Geneva, International Savings Banks Institute (1972b)

16. ISBI: Terminal Project Working Group. Report about Terminal Project. Business Organization and Automation Committee, International Savings Banks Institute, Geneva, 31 October 1972 (BA-41, 1972-10-31) (1972c)

17. ISBI: Automation in Savings Banks. Situation Report at the Beginnning of 1969. Results of an Investigation. International Savings Bank Institute, Amsterdam (mimeo) (1969a)

18. ISBI: Compte Rendu, 4e. Conference Internationale d'Automation. International Savings Banks Institute, Sitges (Barcelona) (1969b)

19. ISBI: Minutes of the 11th Meeting of Study Group on Automation. International Savings Banks Institute, Copenhagen (1968a)

20. ISBI: Report, The Cost of Data Transmission, Beginning 1968. International Savings Banks Institute, Amsterdam (mimeo) (1968b)

21. Knutsson, B. (ed.): Bits \& Bytes ur Datasaabs historia, Tema Bank. Datasaabs Vänner, Linköping (1996)

22. Lacity, M. C., \& Hirschheim, R.: The Information-Systems Outsourcing Bandwagon. Sloan Management Review, 35(1), 73-86 (1993)

23. Larsen, P. E.: Savings Banks Collaboration in Scandinavia. Business Organization and Automation Committee, ISBI, Geneve (1972)

24. Larsen, P. E.: EDP Cooperation between Nordic Countries. 5th Conference on Automation, ISBI, Vienna 9-10 November 1971 (1971)

25. Lundin, P.: Computer in Swedish society. Documenting early use and trends. Springer-Verlag, London (2012)

26. Maixé-Altés, J. C.: The Technological Option of Spanish Savings Banks before the Internet, Circa 1950-1995. Investigaciones de Historia Económica-Economic History Research, 9(3), 175-186 (2013)

27. Maixé-Altés, J. C.: Innovación y compromiso social. 60 años de informatización y crecimiento, 1950-2011[Innovation and Social Compromise. 60 years of computers and Growth, “la Caixa”, 1950-2011], p. 265. Caixa d'Estalvis i Pensions de Barcelona - Edicions 62, Barcelona (2012)

28. Martin, I.: Too Far Ahead of its Time: Barclays, Burroughs, and Real-Time Banking. Annals of the History of Computing, IEEE, 34(2), 5-19 (2012) 
29. Mellbring, R.: Nordiska Terminalprojektet. Tekniskt Genombrott Inom Bankvärlden. Datasaabs Vänners Medlemsblad, 13, 8-14 (2006)

30. Mellbring, R.: D5/20 - minidator och terminaldato. In: Knutsson, B. (ed.) Bits \& Bytes ur Datasaabs historia, Tema Bank, pp. 30-32. Datasaabs Vänner, Linköping (1996)

31. Nolan, M.: Visions of modernity: American business and the modernization of Germany. Oxford University Press, New York (1994)

32. Paju, P.: National Projects and International Users: Finland and Early European Computerization. Annals of the History of Computing, IEEE, 30(4),77-91 (2008)

33. Petersson, T.: Facit and the BESK Boys: Sweden's Computer Industry (1956-1962). Annals of the History of Computing, IEEE, 27(4), 23-30 (2005)

34. Revell, J.: The future of savings banks. A study of Spain and the rest of Europe. Research Papers in Banking and Finance. Institute of European Finance, University College of North Wales, Bangor (1989)

35. Rimvall, P. O.: EDP Services Ofered to Business Customers by Commercial Banks and Savings Banks. 5th Conference on Automation, ISBI, Vienna 9-10 November 1971 (1971)

36. SAC: Report to the ISBI. Sparbankernas Arkitektkontor Och Centralupphandling AB [Architects' Office \& Central Purchaing Department of the Swedish Savings Banks, SAC]. ISBI, Stockholm, 7 November 1972 (ISBI BA-44) (1972)

37. Thodenius, B., Batiz-Lazo, B., Karlsson, T.: The History of the Swedish ATM: Sparframjandet and Metior. In: Impagliazzo, J., Lundin, P., Wangler, B. (eds.): History of Nordic computing 3. IFIP AICT, vol. 350, pp. 92-100. Springer, New York (2011)

38. Wentzel, V.: Bits \& Bytes ur Datasaabs historia, Tema D21. Datasaabs Vänner, Linköping (1994)

39. Wild, R.: Report about Terminals. 5th Conference on Automation, ISBI, Vienna 9-10 November (1971)

40. Yates, J.: Structuring the information age: Life insurance and technology in the twentieth century. Johns Hopkins University Press, Baltimore, Md. ; London (2005) 